第 49 回 獣医疫学会学術集会

シンポジウム“小動物の疫学一エビデンスに基づく獣医療（EBVM）の確立に向けて”

腫瘍治療選択のための疫学解析

廉澤 剛*

酪農学園大学 獣医臨床腫瘍学研究室

\title{
Statistical Evaluation for Clinical Outcomes of Animals with Tumors to Select Optimal Treatments
}

\author{
Tsuyoshi KADOSAWA*
}

Veterinary clinical oncology, Rakuno Gakuen University

\section{Summary}

Animals with tumors are recently treated by surgery, radiotherapy and chemotherapy, similarly to human medicine. To select optimal treatment for each tumor, many studies have been reported in veterinary medicine. Response rate and survival rate are generally used to evaluate each treatment. Prospective cohort study and experimental study, which have comparable internal control and few biases, are ideal, but take much time and cost. Realistically, most clinical studies are categorized to case report, case series study and retrospective study with external control. Our veterinary clinicians should create an environment to design ideal clinical study with statisticians.

\section{はじめに}

動物の腫瘍は，その寿命の延長に伴い増加しており，10 歳以上の犬の半分は腫瘍で死亡していると言われている。 動物の腫瘍は, 人の腫瘍と同様に腫瘍の三大療法と呼ばれ る外科療法, 放射線療法㧍よび化学療法で主に治療される。 しかし, 治瘉できる症例は限られており, 早期にかつ正確 に行える診断法やより効果的な治療法が獣医学臨床および 基礎分野で研究されている。

\section{腫瘍症例の経過}

1) 発がん: 現在のところ, 病理学的な発がんの時期は未 知である。発がんから相当の時間が経過し, 病巣が動 物に影響を及ぼして家族や獣医師によって認識できる 徵候 sign を呈して発病にいたる。人は自覚できる症状

連絡先：廉澤 剛*

酪農学園大学 獣医臨床腫瘍学研究室

于069-8501 江別市文京台緑町 582

Tel \& Fax : 011-388-4889

E-mail : kado@rakuno.ac.jp symptom を訴えることができるが, 動物はできない。 このため, 動物の発病の認識は遅れやすい。

2) 診断：がんの確定診断は病巣の病理学的検査によって 行われる。一方, がんは遺伝子の異常によって生じる ので, 遺伝子検査が急速に進歩している。

3）転移：がんの本態を特徵付ける重要な生物学的事象で リンパ節転移と遠隔臟器への転移がある。腫瘍によっ て早くに起こるものと遅くに起こるものがあると臨床 的には考えられており, リンパ節の触診, 遠隔臟器の 画像検査でマクロレベルの転移が認識される。ミクロ レベルでの転移成立の時期を同定することは現在のと ころできない。

4）治療：大まかには, 局所の病巣は外科療法と放射線療 法で治療され, 転移病巣は化学療法や免疫療法で治療 される。選択すべき治療法は, 腫瘍によって偏りがあり, また同じ腫瘍であっても腫瘍の拡がりによって異なる。 例えば, 遠隔転移率が高い腫瘍であれば, 画像診断で その証拠がなくても検出できない微少転移巣が存在す る可能性があるため, 原発巣を手術で取り除くととも に抗がん剂を用いるのが一般的である。また，腫瘍の 
拡がりは, 原発巣の状態 $(\mathrm{T})$, 所属リンパ節の有無 $(\mathrm{N})$, 遠隔転移の有無（M）を評価して，さらに TNM に基 づいて臨床ステージが決定される。

5）腫瘍病巣の変化：外科療法のように効果が直ちに表れ ずに, 徐々に縮小効果が表れる場合を奏効と言い, 病 巣が認識できなくなった完全奏効 $(\mathrm{CR})$ と半分以上縮 小した部分奏効 (PR) に分けられる。一方, 病巣に大 きな変化がない場合を安定 $(\mathrm{SD})$, 大きく増大した場 合を進行 (PD) と呼ぶ。

6）再発: 外科療法後, あるいは他の治療で病巣が消失し た後に，同部位に再び腫瘍を認めることをいう。ほと んどの再発は, ミクロレベルでの腫瘍細胞の残存によ るが, 一部は発がんしやすい局所環境による再発生も 含まれると考えられている。

7) 死亡: 腫瘍の原発巣や転移巣を制御できないと, 臓器 不全や腫瘍随伴症候等によって死亡する。この場合を 腫瘍死と言い, 他の原因で死亡した場合は他病死と呼 ばれる。

\section{治療効果の解析}

腫瘍の治療効果を判定する指標としては, 腫瘍に対する 直接的な効果（放射線や薬剤等による腫瘍の縮小や腫瘍 マーカーの減少など）や延命効果（生存期間の延長など） が主に用いられる。前者に関しては, 測定可能病変を対象 にした直接的効果判定基準が用いられ，「固形がんの治療 効果判定のためのガイドライン; Response evaluation criteria in solid tumours : RECIST」が世界的に用いられている。後 者の延命効果の指標としては, 生命表法を基本とした累積 生存率がよく用いられ, Kaplan-Meier 法が知られている。

\section{1) RECIST}

治療による腫瘍量の変化を調べることは, 非常に重要で あり, 従来は病変の 2 方向での測定值の積を合計する WHO 規準が用いられてきたが, RECIST では最大長径の 和を用いて CR，PR，SD および PD に分類するようになっ た。一般的には CR と PR を併せた奏効率が治療効果とし て用いられるが, さらに SD を加えた臨床的有用率も最近 用いられている。

\section{2) Kaplan-Meier 法}

獣医学領域の解析では, 観察対象者数が少ない（たとえ ば 1 群 50 症例以下）ので, 生存率の解析に Kaplan-Meier 法が好んで用いられている。直接法では, 消息不明例をす べて死亡として最小生存率, 生存として最大生存率, 除外 して推定生存率として計算する必要があるが, 累積法では 生存期間を数個〜 10 個程度に区切り, 区間ごとの死亡率 と生存率を計算し，これに基づいて全期間を通じての累積 生存率を求める。累積法では, 消息不明例と研究時間切れ
生存例を中途打ち切り (censoring) として加えることがで きる。

\section{臨床研究の分類}

1）記述的研究：主として研究仮説を立ち上げる探索的研 究として行われ, 内部対照 (internal control) がないた め統計解析ができず，信頼性が低い。

・症例報告や症例集積研究など

2）分析的研究：主として規模を拡大して仮説を統計学的 に証明しようとする検証的研究として行われ，内部対 照を設定して統計解析を行うため，信頼性が高い。

A）観察的研究：対象を制御せず，聞き取り調査や一般 的な検査のみを行う

a）横断的研究：因果関係の原因にあたる予測因子 (predictor) と結果にあたるアウトカム (outcome) あるいはエンドポイント (endpoint) を同一の時点 で評価するもので, 両者の関連性を示せても, 因 果関係を強く主張することはできない。

・有病率や検査值の群間比較, 診断法の有用性など

b) 縦断的研究：原因と結果に時間的要素を伴ってい る。

i）後向き研究：現時点の結果を得て過去に遡って 原因を探る研究で，時間や費用がかからない利 点があるが, 選択バイアスや想起バイアスなど の様々なバイアスが入り込むリスクがある。

・ケースコントロール研究, 後向きコホート研究

ii）前向き研究：バイアスをなくすことができる が，時間と費用がかかる。

・前向きコホート研究

B）実験的研究：対象を制御し，薬剤の投与や処置など の介入を行う。

・動物実験, 臨床的な実験研究 (介入研究)

\section{臨床研究の実際}

実際の獣医臨床学での研究では, 内部対照のない記述的 研究，あるいは他の研究者のデー夕を外部対照 (external control）として用いたり，過去の類似条件のデー夕を歴史 的対照 (historical control) として用いたりする “準”分析 的研究が多い。今後, 効果的な治療法を明らかにしていく ために, 介入研究や前向き研究が可能となる環境を整える 必要がある。

\section{臨床研究例}

口腔内悪性黒色腫に罹患した犬 72 症例を対象にして, ステージ別に各治療法の効果を生存期間で分析した研究を 例として示す。分析的研究の中の後向き研究で, 内部対象 


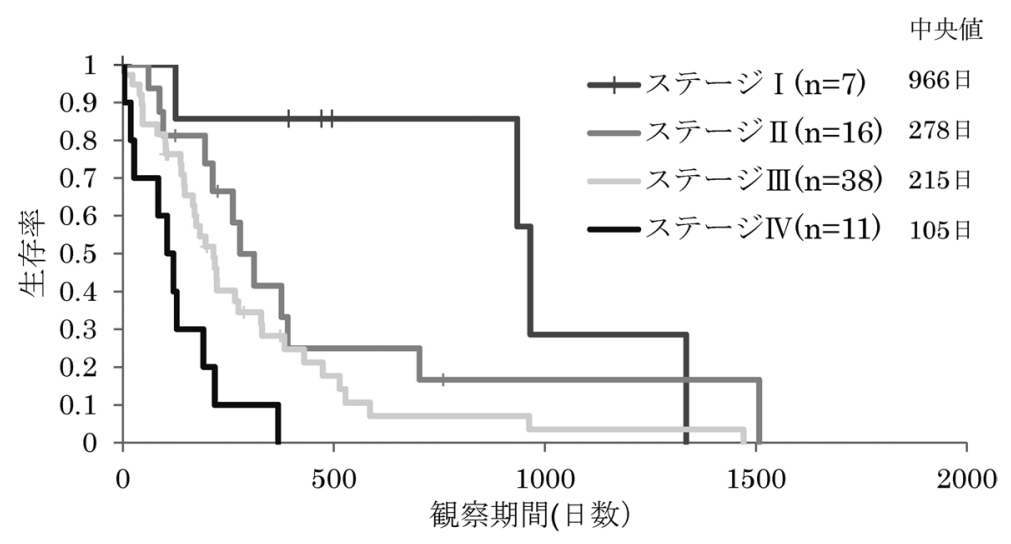

図 1 口腔内悪性黒色腫の犬に扔けるステージごとの生存曲線.

ステージ II と III 以外で有意差あり

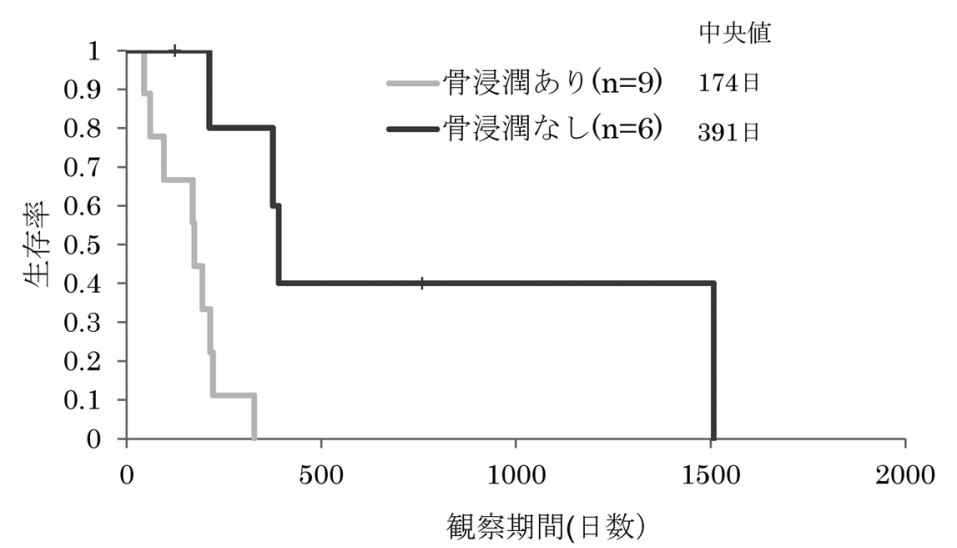

図 2 腫瘍の大きさ $2 \sim 4 \mathrm{~cm}$, 所属リンパ節転移なし, 遠隔転移なしの症例における骨浸潤の有無に よる生存曲線. 有意差あり $(\mathrm{p}<0.01)$

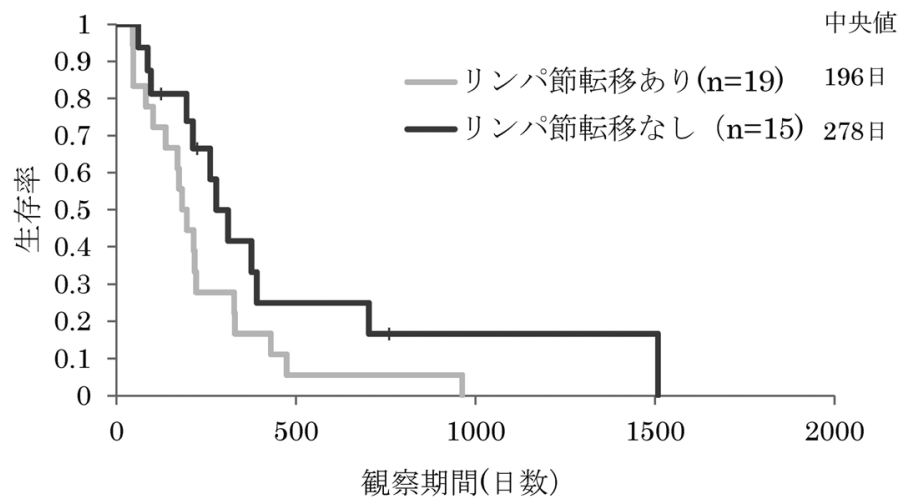

図 3 原発腫瘍が歯肉に発生した症例で腫瘍の大きさ $2 \sim 4 \mathrm{~cm}$, 遠隔転移なしの症例に抢けるリンパ 節転移の有無による生存曲線. 有意差なし 
を有するが，症例の家族と担当医による治療法の選択バイ アスが存在する。

\section{「WHO のステージ分類に基づいた口腔内悪性 黒色腫罹患犬 72 症例の回顧的研究」}

\section{【はじめに】}

犬の口腔内悪性黒色腫は発生率が高く, その生物学的挙 動も悪いため, 新たな治療戦略が切望されている腫瘍の一 つであるが，1980 年にWHO で制定されたステージ分類 に基づいて治療法が検討されているにすぎない。そこで, 口腔内悪性黒色腫罹患犬の回顧的調査を行い, WHO の久 テージ分類法と各治療法の成績について検討した。

\section{【材料と方法】}

2004 年 4 月から 2011 年 8 月までに本学附属動物病院に 来院し, 病理組織診断にて口腔内悪性黒色腫と診断された 72 症例を用いた。初診時の腫瘍発生部位，大きさ，骨浸 潤の有無, 及びリンパ節・遠隔臟器への転移の有無を基に, WHO のステージ分類を行った。治療群をそれぞれ根治目 的群（積極的手術あるいは放射線療法土全身療法），緩和 目的群（減量術あるいは緩和的放射線療法）, 及び無治療 群に分類した。各ステージ及び各治療群の生存期間, さら にステージング決定要因である骨浸潤, リンパ節転移の有 無などが生存期間に及ぼす影響について調べた。

\section{【結果】}

腫瘍の発生部位は歯肉が最も多く, 口唇・頬粘膜, 舌, 軟・硬口蓋，扁桃の順で発生が認められた。腫瘍の大きさ は中央值 $2.7(0-11) \mathrm{cm}$ ，骨浸潤は 58\%（不明 30\%)，リ ンパ節転移は $41 \%$ （不明 $18 \%$ ），遠隔転移は $12 \%$ （不明 $0 \% ） の$ 症例で認められた。ステージ I $(\mathrm{n}=7)$, II $\quad(\mathrm{n}=$ 16），III $(\mathrm{n}=38)$, IV $(\mathrm{n}=11)$ の各生存期間の中央值は 966，278，215，105 日でステージ II と III 以外で有意差を 認めた (図 1)。腫瘍の大きさが $2 \mathrm{~cm}$ 以上 $4 \mathrm{~cm}$ 未満の場合, 骨浸潤の有無で生存期間に有意差を認めたが (図 2),リ ンパ節転移の有無で有意な差は認められなかった（図 3)。 【考察】

ステージ II と III の症例群において，骨浸潤の有無で生存 期間に有意差を認めたものの, リンパ節転移の有無で生存 期間に有意な差を認めなかったことから，腫瘍が $2 \mathrm{~cm}$ を 超えた場合, 臨床的にリンパ節転移がないと判断しても, すでに細胞レベルでのリンパ節転移あるいは遠隔転移が成 立している可能性が高いと考えられた。これらのことから， ステージ II と III を分別するには新たな評価項目の必要性が 示唆された。また，根治を目指した積極的局所療法及び全 身療法によって, 生存期間が延長するものの, 有意な差は 認められず， $60 \%$ 以上の症例が肺転移によって死亡して いることから，効果的な全身療法の確立が望まれる。 